\title{
Inter Simple Sequence Repeat molecular markers to reveal the genetic diversity of superior durian of Gunungpati, Semarang, Indonesia
}

\author{
EVY NASRIKA, AMIN RETNONINGSIH* \\ Department of Biology, Faculty of Mathematics and Natural Sciences, Universitas Negeri Semarang. Jl. Raya Sekaran, Gunungpati, Semarang City, \\ Central Java, Indonesia. Tel./fax.: +62-813-16535512, •email: aminretnoningsih2016@mail.unnes.ac.id
}

Manuscript received: 06 June 202. Revision accepted: 30 August 2021.

\begin{abstract}
Nasrika E, Retnonongsih A. 2021. Inter Simple Sequence Repeat molecular markers to reveal the genetic diversity of superior durian of Gunungpati, Semarang, Indonesia. Biodiversitas 22: 4054-4059. Kalimantan is the center of many tropical fruits, including durian. One of the edible durians and favorited by many is Durio zibethinus, which has many superior varieties. Almost all regions in Indonesia have superior durian varieties; for example, superior durian Gunungpati from Gunungpati Sub-district, the center for producing durian in Semarang City, Central Java, Indonesia. ISSR analysis was carried out to reveal the genetic diversity of the superior durian Gunungpati. DNA isolation of 16 superior durians used the modified CTAB method. The genomic DNA was amplified using 10 ISSR primers and then electrophoresed using $2 \%$ agarose gel. Data were analyzed using NTSYS PC version 2.02. The resulting allele has a relative size of $220 \mathrm{bp}-1800 \mathrm{bp}$, with $87.9 \%$ are polymorphic. The similarity coefficient of 16 varieties was ranged between $0.54-$ 0.88. All the superior durian varieties examined were different accessions so that each variety has the potential to be registered as a new variety of superior Indonesian durian. Specific alleles are found in G1, G3, G7, G8, and G13, which can be an identity of these varieties.
\end{abstract}

Keywords: Durio zibethinus, genetic diversity, Gunungpati, ISSR, superior durian

\section{INTRODUCTION}

Kalimantan is the center of the diversity of durian species (Durio spp) in Indonesia and the world. Twenty in every thirty durians species are found in this area, and nine are edible (Uji 2005). One of the most popular edible durians is Durio zibethinus. The taste, color, and aroma of this durian species are the most preferred by consumers, making its economic value the highest compared to other edible durians. Therefore, the distribution and cultivation of $D$. zibethinus in Indonesia are intensive, including in Java. Durio zibethinus is the only durian species with many varieties as genetic diversity within the species (Hikmah et al. 2016; Angeliena et al. 2019; Habibah et al. 2019; Songnuan et al. 2019; Hannum et al. 2020; Yursak et al. 2020; Maranatha et al. 2020).

Superior durian varieties are always in demand, especially during the durian harvest. Almost all regions in Indonesia have excellent durian varieties with distinctive tastes, colors, and aromas. However, Indonesia's superior durian database is still incomplete, considering many superior varieties have not been recorded. The completeness of data on superior durian varieties is essential as the basis for durian agribusiness development in each durian center area. Indonesia also can become a producer and exporter of superior durians because the vast regions of Indonesia are suitable for durian cultivation. Therefore, an analysis of genetic diversity and identification of superior durians in each area needs to be carried out to determine the priority for durian varieties developed in that region.

Gunungpati sub-district is a durian-producing center in the Semarang region, which has several superior durian varieties. The condition of its aril characterizes superior durians. The superior durian's aril has a slightly bitter and fluffier taste, creamy, yellow to orange in color; the aroma is not too strong. The thickness of the aril is more than 1.5 $\mathrm{cm}$ (Tirtawinata et al. 2016). The population of superior durian Gunungpati is limited, so its productivity is low. Information about the certainty of superior durian Gunungpati variety is not available. Therefore, farmers face difficulties in choosing superior varieties to cultivate. Research on superior durians in Gunungpati can ensure their genetic diversity and cultivars' identity as necessary information in durian cultivation.

The plants' genetic diversity can be analyzed using morphological, isozyme, and molecular markers. The use of morphological traits is known to be less accurate because the environment influences them. Plant phenotypes were resulted from interactions between genetics and the environment, making them unstable (Pandin 2010; Mijnsbrugge and Moreels 2020). Isozymes are considered better than morphological markers, although they still have some limitations because they are influenced by the organ's type and age being analyzed. Molecular markers are more accurate than other markers (Butiuc-Keul et al. 2019; Ahmad et al. 2021). The environment does not influence this marker, so it is more stable (Yulita 2013). Analysis of plant diversity can be carried out using several molecular markers such as restriction fragment length polymorphism (RFLP), simple sequence repeats (SSR), and inter-simple sequence repeats (ISSR). Analysis of the genetic diversity of the superior durian Gunungpati using ISSR because this marker is simple, easy, and reproducible $(\mathrm{Ng}$ and Tan 2015) and can distinguish varieties of the same species 
(Valiyeva et al. 2019). This study aims to analyze the genetic diversity of superior durians in Gunungpati based on ISSR molecular markers.

\section{MATERIALS AND METHODS}

\section{Plant materials and study area}

The research was conducted at the Molecular Biology Laboratory and Research Laboratory, Department of Biology, Faculty of Mathematics and Natural Sciences, Universitas Negeri Semarang, from January to December 2020. After prior selection, the research subjects were 16 varieties of superior durians in Gunungpati by exploring and interviewing durian farmers in the region. The young durian leaves are taken from the end of the branch on the first leaf to the third leaf. Young leaves are chosen because they do not contain mucus, polysaccharides, and phenolics found in old leaves. Therefore, DNA isolation using old leaves is challenging to get sufficient DNA purity for PCR purposes (Hanin and Pratiwi 2017). Furthermore, unlike the superior durian varieties in other regions, the Gunungpati superior durian variety is not named, only known as "durian unggul Gunungpati." Therefore, the superior durian varieties used in this study were coded as G1-G16.

\section{Procedures}

\section{Genomic DNA extraction}

Genomic DNA isolation was carried out using the CTAB method by Vanijajiva (2012), modified by Solikin et al. (2017). Young durian leaves were cleaned and weighed 0.025 grams, then crushed using a tissue layer. Extraction buffer as much as $1 \mathrm{~mL}$ (CTAB 2\%, Tris-HCL $0.1 \mathrm{M}$ pH 8 100, EDTA $0.02 \mathrm{M}$, PVP 1\%, NaCl 1.4 M, $\beta$ mercaptoethanol $0.3 \%$ ) was added in the tube and homogenized then incubated at $60^{\circ} \mathrm{C}$ for 30 minutes. A total of $750 \mu \mathrm{l}$ of PCI was added and then centrifuged at $10,000 \mathrm{rpm}$ for 15 minutes. The supernatant was transferred to a new microtube, and RNAse $2.5 \mu \mathrm{l}$ was added. This solution was incubated at $37^{\circ} \mathrm{C}$ for 30 minutes, then added $750 \mu \mathrm{L}$ of absolute cold ethanol and centrifuged at $12,000 \mathrm{rpm}$ for 5 minutes. DNA pellets were washed using $750 \mu \mathrm{L}$ ethanol $70 \%$ and centrifuged at $12,000 \mathrm{rpm}$ for 5 minutes. The DNA pellets were dried, and $100 \mu \mathrm{L}$ of TE buffer was added.

\section{PCR (Polymerase Chain Reaction)}

DNA amplification using peqSTAR $2 \mathrm{X}$ Thermocycle with 10 ISSR primers is shown in Table 1 . The composition of each $12,5 \mu \mathrm{L}$ PCR reactions for DNA amplification is as follows: $1 \mu \mathrm{L}$ DNA sample $(50 \mathrm{ng} / \mu \mathrm{L}$ concentration), $1 \mu \mathrm{L} \quad$ ISSR primer $(10 \quad \mathrm{ng} / \mu \mathrm{L}$ concentration), 6.25 $\mu \mathrm{L}$ Dream Taq Green PCR Master Mix (2X), and $4.25 \mu \mathrm{L}$ Nuclease Free Water. PCR stages using ISSR primer were programmed for pre-denaturation step at $95^{\circ} \mathrm{C}$ for 4 minutes, followed by 35 cycles each consisting of a denaturation step at $95^{\circ} \mathrm{C}$ for 30 seconds, an annealing step $36.7^{\circ} \mathrm{C}-53,7^{\circ} \mathrm{C}$ for 30 seconds, and an extension at $72^{\circ} \mathrm{C}$ for 1 minute. A final extension terminated amplification at $72^{\circ} \mathrm{C}$ for 10 minutes.
Table 1. ISSR primers for analyzing superior durian Gunungpati diversity

\begin{tabular}{llc}
\hline Primer & Sequence & $\begin{array}{c}\text { Annealing } \\
\text { temp. }\left({ }^{\circ} \mathbf{C}\right)\end{array}$ \\
\hline ISSR1 & 5'-AGGAGGAGGAGGAGG-3' & 48.4 \\
ISSR2 & 5'-AGAAGAAGAAGAAGT-3' & 36.7 \\
ISSR4 & 5'-GAGGAGGAGGAGGAGAC-3' & 47.3 \\
ISSR5 & 5'-GAGGAGGAGGAGGAGAT-3' & 44.0 \\
ISSR 10 & 5'-GTGTGTGTGTGTGTGTGTA-3' & 49.4 \\
PKBT 2 & 5'-ACACACACACACACA-3' & 47.1 \\
PKBT 7 & 5'-GAGAGAGAGAGAGAGAGAA-3' & 43.9 \\
PKBT 8 & 5'-GAGAGAGAGAGAGAGAGAC-3' & 53.7 \\
PKBT 9 & 5'-GAGAGAGAGAGAGAGAGAT-3' & 50.9 \\
PKBT12 & 5'-GTGTGTGTGTGTGTGTGTT-3' & 44.9
\end{tabular}

\section{Electrophoresis}

DNA amplification was visualized using electrophoresis with $2 \%$ agarose and 100 bp GeneRuler at 100 volts for 45 minutes.

\section{Data analysis}

Each DNA band in the 2\% agarose gel is an ISSR allele in certain durian varieties. A score of 1 is given if there is an allele and 0 if there is no allele. The presence of alleles at each ISSR locus became a reference for analyzing genetic diversity, calculated based on the number of alleles and the percentage of monomorphic and polymorphic alleles. The similarity between durian varieties of Gunungpati was analyzed using Similarity for Qualitative (SIMQUAL) with DICE coefficient. The grouping of durian varieties is shown through a dendrogram constructed using the sequential, agglomerative, hierarchical, and nested (SAHN)-Unweighted pair-group, arithmetic average (UPGMA) program in (NTSYSpc) version 2.02 (Rohlf 1998).

\section{RESULTS AND DISCUSSION}

\section{Polymorphism of ISSR superior durian Gunungpati allele}

All ISSR alleles found in 16 varieties of superior durian Gunungpatis using 10 ISSR primers are shown in Table 2. The highest number of alleles were produced by ISSR 1 and ISSR 5 primers (10 alleles), and the least number of alleles primers were produced by ISSR 10 primer (3 alleles). The relative size of the alleles produced is between $220 \mathrm{bp}-1800 \mathrm{bp}$. According to Ng and Tan's (2015), the standard size range for the ISSR band score is usually in the $100-2000$ bp range. Band size $<100 \mathrm{bp}$ is usually less sharp and becomes a primer-dimer amplification product, while band $>2000 \mathrm{bp}$ is challenging to store during PCR. It has strength and tends to have low reproducibility. Based on 10 ISSR primers, it showed a high level of genetic diversity of superior durian Gunungpati with allele polymorphism of $87.9 \%$. The allele polymorphism was higher than Vanijajiva (2012) results, which analyzed 14 Thai durian varieties using 5 ISSR primers, which resulted in $38 \%$ allele polymorphism. The genetic diversity of durian in Indonesia is getting higher with the increasing 
number of varieties analyzed. Fifty-five varieties of durian Kundur Island, Riau Archipelago, were analyzed using 11 ISSR primers to produce $93.25 \%$ allele polymorphism (Angeliena et al. 2019). The high genetic diversity of durian in Indonesia is similar to the genetic diversity of other fruits in Indonesia, and the more accessions analyzed, the more alleles produced (Retnoningsih et al. 2011). Despite the number of accessions added, the constant value of genetic diversity indicates that the plant germplasm is genotypically uniform. Indonesia has various sources of germplasm of fruit plants with high genetic diversity (Retnoningsih et al. 2011; Retnoningsih et al. 2014; Rahmawaty et al. 2019; Fitmawati et al. 2020; Sembiring et al. 2020; Suwardi et al. 2020; Tolangara et al. 2020). The results showed that durian genetic diversity was high even though the study was limited to the Gunungpati area; 16 durian varieties showed different genotypes in $D$. zibethinus. Stuessy et al. (2014) argue that the distribution area of plants affects their diversity. Plants with a wide distribution area have a higher level of diversity than plants with a narrow distribution.

The genetic diversity of certain plant species arises due to several factors. One of the factors causing genetic diversity in $D$. zibethinus is the biology of pollination. Durian flowers are hermaphrodites, so self-pollination is possible; pollen from the same flower or different flowers pollinates the stigma of flowers on the same tree. The diversity of these self-compatible pollination results was lower than that of pollen pollinated from other durian trees. Durian flowers are more incompatible with the stigma position than the anther, and physiologically, the receptive time between stigma and dehiscent anther is different. This situation causes pollen to tend to cross-pollinate with flowers on separate trees. The chances of flower pollination between varieties are higher than self-pollination (Honsho et al. 2007; Bumrungsri 2009). This explanation is relevant to the genetic diversity of durian in Gunungpati which are grown mostly with seeds. The durian seeds are made from cross-pollination, which brings characteristics to their two parents (Indriyani et al. 2012). Another factor causing the emergence of diversity is mutation. These mutations are rare and challenging to identify conventionally (Riupassa et al. 2015) because morphological changes do not always follow mutations.

\section{Superior durian Gunungpati specific allele}

The visualization results showed that several durian varieties had specific alleles in different primers (Figure 1). Specific alleles were detected in 5 superior durian varieties of Gunungpati. Certain alleles of each variable have different sizes. Specific alleles of G2 and G7 varieties were detected in ISSR 1 primer, G3 variety in ISSR 4 primer, G11 variety in ISSR 5 primer, and G8 variety in PKBT 12 primer. Further studies need to be carried out to ensure that these specific alleles become varietal loci and can be reproduced to obtain stable markers. Another molecular marker that can strengthen specific attributes is the SSR, which is codominant and unique (Riupassa et al. 2015).

\section{Similarities of superior durian Gunungpati}

The result of the cluster analysis showed that the 16 varieties of superior durian Gunungpati differed from one another (there are no varieties that had $100 \%$ similarity) with a similarity coefficient of 0.54-0.88 (Figure 2). Similarity coefficients are coefficients that represent the level of similarity between two varieties. Dendrogram forms two main clusters, namely clusters A and B, at a similarity coefficient of 0.54 . Cluster A consists of 2 subclusters, namely sub-clusters A1 and A2. Sub-cluster A1 consists of 12 varieties, namely varieties G1, G2, G4, G7, G8, G9, G11, G12, G13, G14, G15, and G16. Sub-cluster A2 only consists of 2 varieties of durian, namely varieties G3 and G10. Cluster B consists of 2 varieties of durian, namely varieties G5 and G6.

Tabel 2. The ISSR allele for superior durian Gunungpati, Indonesia

\begin{tabular}{|c|c|c|c|c|c|}
\hline Name of primers & $\begin{array}{ll}\begin{array}{l}\text { Relative } \\
\text { (bp) }\end{array} & \text { size } \\
\end{array}$ & $\begin{array}{l}\text { Number } \\
\text { of allele }\end{array}$ & $\begin{array}{l}\text { Number of } \\
\text { Polymorphic allele }\end{array}$ & $\begin{array}{l}\text { Number of } \\
\text { Monomorphic allele }\end{array}$ & Polymorphism (\%) \\
\hline ISSR 1 & $290-1500$ & 10 & 8 & 2 & 80 \\
\hline ISSR 2 & $580-1500$ & 5 & 5 & 0 & 100 \\
\hline ISSR 4 & $500-1800$ & 6 & 5 & 1 & 83.3 \\
\hline ISSR 5 & $350-1250$ & 10 & 9 & 1 & 90 \\
\hline ISSR 10 & $580-900$ & 3 & 2 & 1 & 66.7 \\
\hline PKBT 2 & $380-1300$ & 5 & 5 & 0 & 100 \\
\hline PKBT 7 & $400-1400$ & 6 & 6 & 0 & 100 \\
\hline PKBT 8 & $400-1200$ & 7 & 7 & 0 & 100 \\
\hline PKBT 9 & $220-1600$ & 8 & 7 & 1 & 87.5 \\
\hline PKBT 12 & $480-1700$ & 7 & 5 & 2 & 71.5 \\
\hline Total & & 67 & 59 & 8 & 879 \\
\hline Average & & 6.7 & 5.9 & 0.8 & 87.9 \\
\hline
\end{tabular}


Varieties in the same cluster have a similar allele profile (Yulita and Murnianjari 2010). The similarity of these allele profiles is in line with the kinship relationship; the higher similarity of the allele profiles between varieties indicates that these individuals have a close phenetic relationship. The highest similarity was found in varieties G14 and G16, with a coefficient of 0.88 . The higher the similarity index indicates that these individuals have a close phenetic similarity and vice versa (Daryono et al. 2019). None of the cultivars were identified as $100 \%$ similar to each other. All the varieties studied could be ascertained from seeds resulting from natural crosses or seedlings produced by vegetative propagation of different varieties. We cannot guarantee that the fruit by seed is the same as the female parent; it depends on the male parent's genotype. Superior durians with specific alleles are in subcluster A except for G3, which is in sub-cluster A2. The finding of 16 superior durians from Gunungpati enriched the database of superior Indonesian durians, which could be priority candidates for cultivation and become the distinctive features of durian agribusiness in Indonesia. Each superior durian Gunungpati studied can be registered as a new variety of superior Indonesian durian.

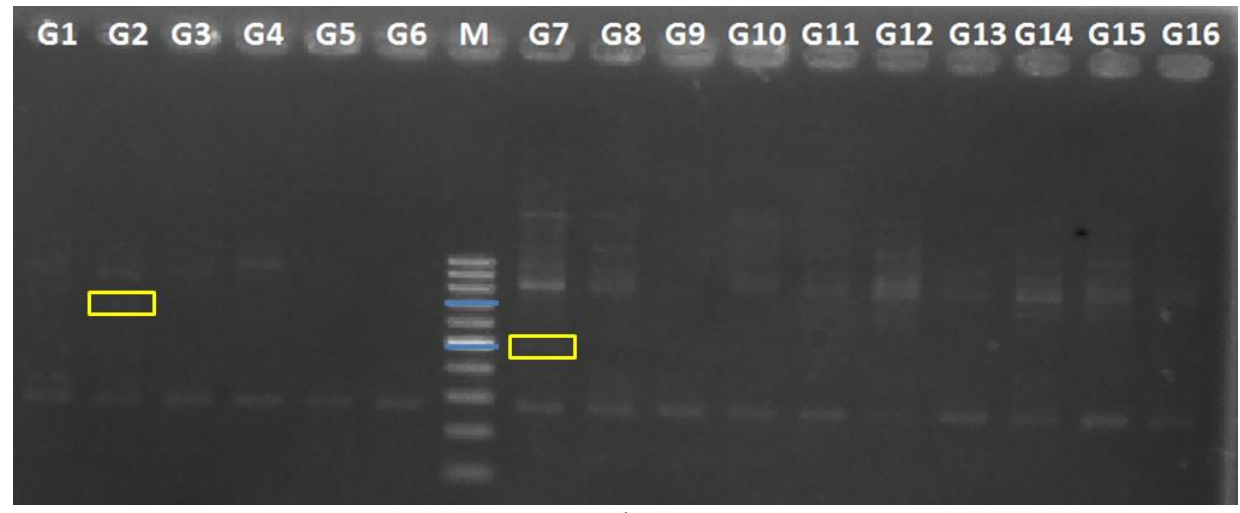

A

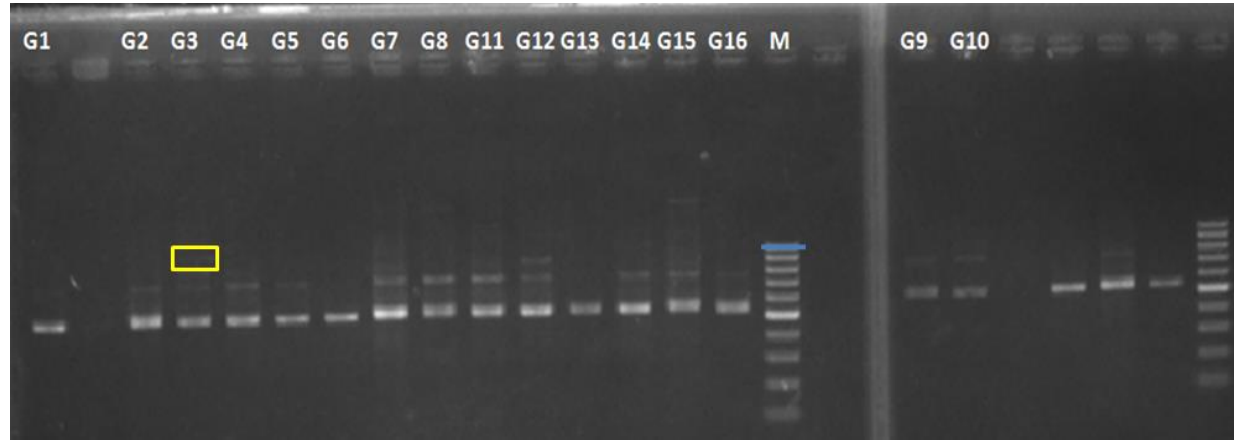

B

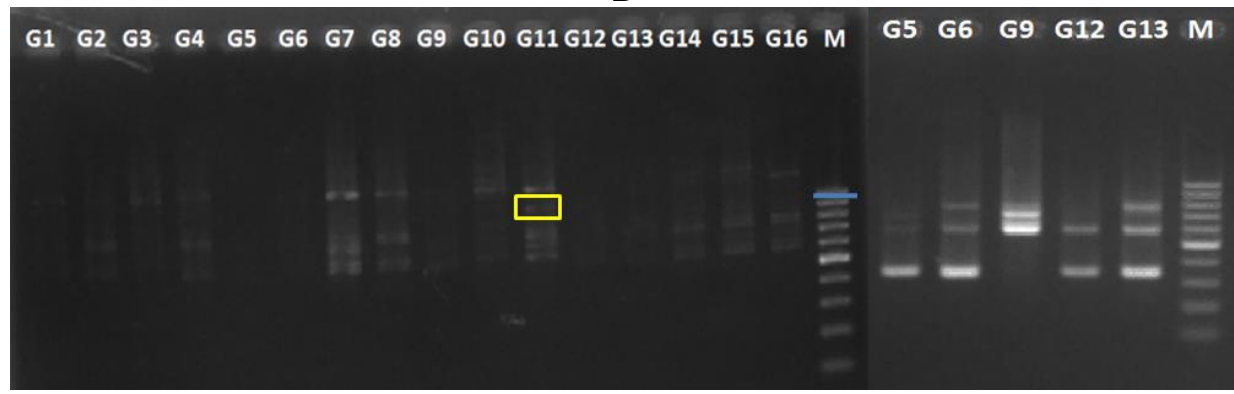

C

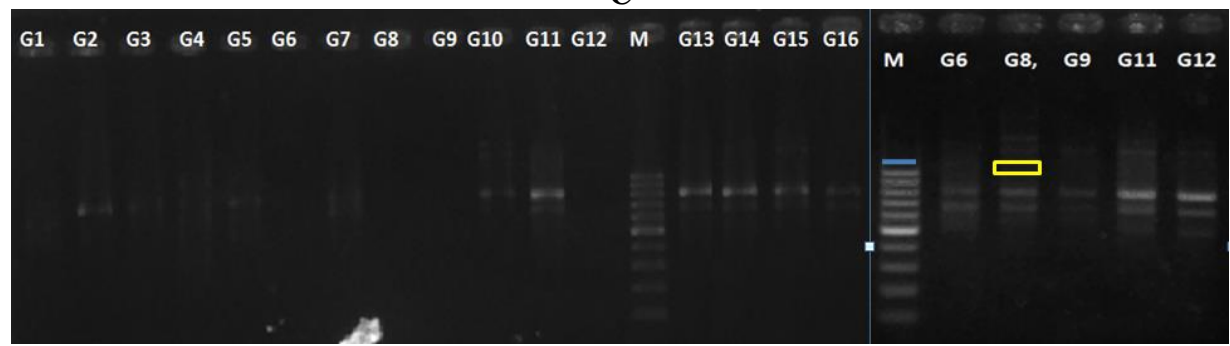

D

Figure 1. Spesific allele in several varieties (A) ISSR 1 primer, (B) ISSR 4 primer, (C) ISSR 5 prier and (D) PKBT 12 primer. 


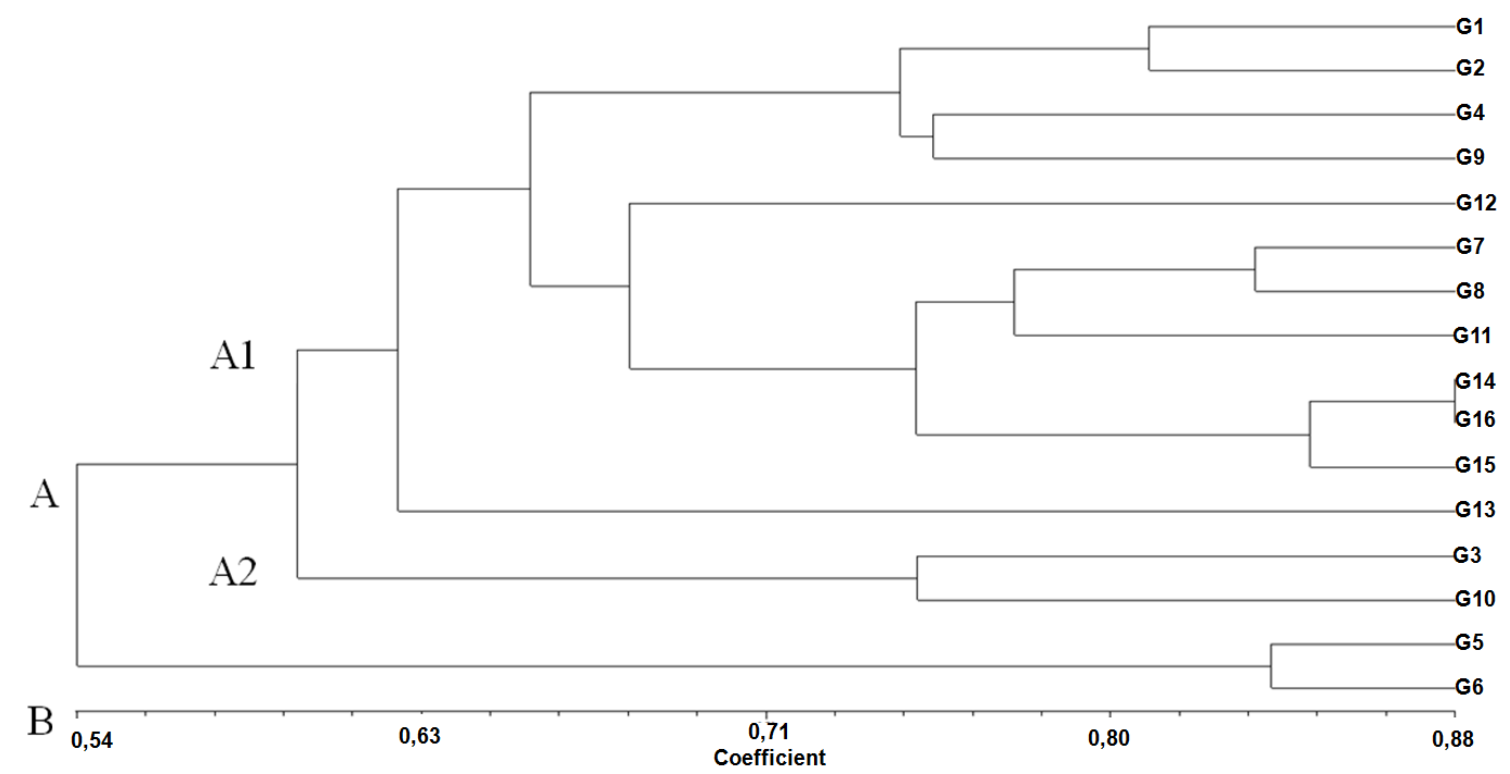

Figure 2. Dendrogram of 16 superior durian Gunungpati varieties, Indonesia

In conclusion, this study can reveal that the genetic diversity of 16 varieties of superior durian Gunungpati based on 10 ISSR primers is high, with polymorphic alleles of $87.9 \%$. We found specific alleles at G1, G3, G7, G8, and G13 that can be used to identify the varieties. All durian varieties studied were different varieties of durian because there was no $100 \%$ similarity found.

\section{ACKNOWLEDGEMENTS}

We would like to thank the Head of the Biology Laboratory of Universitas Negeri Semarang, Indonesia for allowing the use of laboratory facilities and Gunungpati durian farmers for permitting us to observe their durian plants to be researched.

\section{REFERENCES}

Ahmad R, Anjum MA, Naz S, Balal RM. 2021. Applications of molecular markers in fruit crops for breeding programs. Phyton 90 (1): 17-34. DOI: 10.32604 /phyton.2020.011680.

Angeliena A, Ma'ruf A, Sidiq HA, Anggraito YU, Habibah NA, Huyop FZ, Retnonigsih A. 2019. The diversity of superior Indonesian durians based on molecular markers. Proceeding of the 2nd International Conference on Biosciences and Medical Engineering. Bali, 11-12 April 2019. [Indonesian]

Bumrungsri S, Sripaoraya E, Chongsiri T, Sridith K, Paul A, Racey R. 2009. The pollination ecology of durian (Durio zibethinus, Bombacaceae) in southern Thailand. J Trop Ecol 25: 85-92. DOI: 10.1017/S0266467408005531.

Butiuc-Keul A, Coste A, Farkas A, Cristea V, Isac V, Halmagyi A. 2019. Molecular characterization of apple (Malus $\times$ domestica Borkh.) genotypes originating from three complementary conservation strategies. Turk J Agric For 43: 464-477. DOI: 10.3906/tar-1803-3.

Daryono BS, Subiastuti AS, Fatmadanni A, Sartika D. 2019. Phenotypic and genetic stability of new indonesian melon cultivar (Cucumis melo L.'Melonia') based on ISSR markers. Biodiversitas 20 (4): 10691075. DOI: $10.13057 /$ biodiv/d200419.
Fitmawati F, Ramadhan S, Sofiyanti R. 2020. Inventory of mango diversity (Mangifera L.) in Bengkulu Province. Intl J Ecophysiol 2 (1): 35-42.

Habibah NA, Anggraito YU, Abdullah M, Sidiq HA, Angeliena A, Ma'ruf A, Huyop FZ, Retnoningsih A. 2019. Morphological based diversity analysis of durian from Kundur Island, Indonesia. Proceeding of the 2nd International Conference on Biosciences and Medical Engineering. Bali, 11-12 April 2019. [Indonesian]

Hanin NNF, Pratiwi R. 2017. Kandungan fenolik, flavonoid, dan aktivitas antioksidan ekstrak daun paku laut (Acrostichum aureum L.) fertil dan steril. J Trop Biodiv Biotech 2: 51-56. [Indonesian]

Hannum S, Wahyuningsih H, Sinaga R, Pasaribu N, Hartanto A. 2020. Genetic diversity among durian (Durio zibethinus Murr.) Populations From Nias Island, Indonesia using RAPD markers. Appl Ecol Environ Res 18 (5): 7337-7351. DOI:10.15666/aeer/1805_73377351

Hikmah RU, Retnoningsih A, Habibah NA. 2016. Keragaman durian berdasarkan fragmen Internal Transcribed Spacers (ITS) DNA ribosomal melalui analisis PCR-RFLP. J MIPA 39 (1): 11-18. [Indonesian]

Honsho C, Somsri S, Tetsumura T, Yamashita K, Yonemori K. 2007. Effective pollination period in durian (Durio Zibethinus Murr.) and the FACTORS REGULATING it. Scientia Horticulturae, 111: 193196. DOI: 10.1016/j.scienta.2006.10.016.

Indriyani NLP, Hadiati S, Nasution F, Edison E, Sudjijo S, Irawati Y. 2012. Maternal and paternal effect on the characters of durian (Durio zibethinus Murr.) fruit from cross-pollination. J Fruit Ornam Plant Res 20 (2): 23-33.

Maranatha CR, Koimah N, Artika J. 2020. Keanekaragaman morfologi durian lokal (Durio zibethinus Murr) di Aceh Tamiang, Indonesia. Prosiding Seminar Nasional Peningkatan Mutu Pendidikan 1 (1): 357 360. [Indonesian]

Mijnsbrugge KV, Moreels S. 2020. Varying levels of genetic control and phenotypic plasticity in timing of BudBurst, flower opening, leaf senescence and leaf fall in two common gardens of Prunus padus L. Forests. 11: 1-15.

Ng WL, Tan SG. 2015. Inter Simple Sequence Repeat markers: Are we doing it right ?. ASM Sci J 9 (1): 30-39.

Pandin DS. 2010. Penanda DNA untuk pemuliaan tanaman kelapa (Cocos nucifera L). Perspektif 9 (1): 21-35. [Indonesian]

Rahmawaty R, Situmorang LKN, Rauf A, Batubara R. 2019. GIS based: mapping of multy purpose tree species (Durio zibethinus) in Perkebunan Tambunan Village, Langkat District, North Sumatera Province, Indonesia. IOP Conf Ser Earth Environ Sci 454: 012147. DOI: 10.1088/1755-1315/454/1/012147.

Retnoningsih A, Megia R, Hartana A. 2011. Microsatellite markers for classifying and analysing genetic relationship between banana 
cultivars in Indonesia. Acta Horticulturae 897: 153-159. DOI 10.17660/ActaHortic.2011.897.16.

Retnoningsih A, Megia R, Hartana A. 2014. Phylogenetic relationships of indonesian banana cultivars inferred from TRNL-F Intergenic Spacer of chloroplast DNA. Floribunda 4 (8): 202-211. DOI: 10.32556/floribunda.v4i8.2014.116.

Riupassa PA, Chikmawati T, Miftahudin M, Suharsono S. 2015. The molecular diversity based ISSR of Durio tanjungpurensis Originating from West Kalimantan, Indonesia. Makara J Sci 19 (1): 27-36. DOI: 10.7454/mss.v19i1.4479.

Rohlf FJ. 2000. Numerical Taxonomy and Multi-Variate Analysis System, Version 2.1. Applied Biostatistics. New York, USA.

Sembiring MB, Rahmi D, Maulina M, Tari V, Rahmayanti R, Suwardi AB. 2020. Identifikasi karakter morfologi dan sensoris kultivar mangga (Mangifera indica L.) di Kecamatan Langsa Lama, Aceh, Indonesia. Jurnal Biologi Tropis 20 (2): 179-184. [Indonesian]

Solikin A, Retnoningsih A, Rahayu ES. 2017. Karakterisasiaksesi durian lokal koleksi Hortimart Agro Centre Jawa Tengah menggunakan penanda molekuler Inter Simple Sequence Repeats (ISSR). Floribunda 5 (7): 267-276. DOI: 10.32556/floribunda.v5i7.2017.189. [Indonesian]

Songnuan W, Pichakum A, Traiperm P, Rungjangsuwan E, Siriwattanakul U, Leeratsuwan N, Chareonsap PP, Kulpradit K, Somsri S, Swangpol SC. 2019. Diversity of durian (Durio zibethinus L.) from Nonthaburi, Thailand based on morpho-palatability characteristics and Simple Sequence Repeat Markers. Agric Nat Resour 53: 218-227. DOI: 10.34044/j.anres.2019.53.3.02.

Stuessy TF, Takayama K, Sepulveda PL, Crawford DJ. 2014 Interpretation of patterns of genetic variation in endemic plant species of Oceanic Islands. Bot J Linn Soc 174: 276-288. DOI 10.1111/boj.12088
Suwardi AB, Navia ZI, Harmawan T, Syamsuardi S, Mukhtar E. 2020. Ethnobotany and conservation of indigenous edible fruit plants in South Aceh, Indonesia. Biodiversitas 21 (5): 1850-1860. DOI: 10.13057/biodiv/d210511.

Tirtawinata M, Panca JR, Leni HA. 2016. Durian: Pengetahuan Dasar Untuk Pecinta Durian. Agro Flo, Jakarta. [Indonesian]

Tolangara A, Corebima AD, Mas'ud, Sundari S. 2020. Short communication: genetic diversity of lemon (Citrus spp.) from Ternate Island (Indonesia) based on morphological and molecular characters. Biodiversitas 21 (5): 1908-1913. DOI: 10.13057/biodiv/d210517.

Uji T. 2005. Keanekaragaman jenis dan sumber plasma nutfah durian (Durio spp.) di Indonesia. Buletin Plasma Nutfah 11: 28-33.

Valiyeva LS, Rahimova GK, Nabiyeva NA. 2019. Application of ISSR markers for study of genetic polymorphism of dark grain maize varieties. In: Current Challenges in Plant Genetics, Genomics, Bioinformatics, and Biotechnology 2019: 39-41. DOI: 10.18699/ICGPlantGen2019-10.

Vanijajiva O. 2012. The application of ISSR markers in genetic variance detection among durian (Durio zibethinus Murr.) cultivars in the Nonthaburi Province, Thailand. Procedia Eng 32: 155-159. DOI: 10.1016/j.proeng.2012.01.1250

Yulita KS, Murnianjari M. 2010. Keragaman genetik beberapa klon durian (Durio zibethinus Murray) asal Jawa Barat berdasrkan Sidik Random Amplified Polimorphic DNA. Berita Biologi 10 (3): 269-275. [Indonesian]

Yulita KS. 2013. Identifikasi molekuler pohon induk beberapa varietas durian asal Jepara menggunakan Random Amplified Polimorphic DNA. J Hort 23 (2): 99-106. [Indonesian]

Yursak Z, Amanda UD, Widiyastuti D, Susilawati PN. 2020. Morphological characterization of local durian of Banten Province, Indonesia. IOP Conf Ser Earth Environ Sci 591: 012048. DOI: DOI: $10.1088 / 1755-1315 / 591 / 1 / 012048$. 